Article page 1479.

\title{
Commentary: I fix what's broken-including the heart
}

\author{
Michele Di Mauro, MD, PhD, MSc Biostat, ${ }^{a}$ \\ Barbara Ghinassi, $\mathrm{MD}, \mathrm{PhD},{ }^{\mathrm{b}}$ and \\ Angela Di Baldassarre, $\mathrm{MD}, \mathrm{PhD}^{\mathrm{b}}$
}

Myocardial infarction causes irreversible heart tissue damage, leading to scar formation and inevitably ischemic heart failure (IHF). It affects roughly 6 million Americans, one half of whom will die within the first 5 years of diagnosis. ${ }^{1}$ Despite the advantages of percutaneous coronary intervention, time (90-minute door-to-balloon) remains still a limitation to avoid scarring and fibrosis. ${ }^{2}$

Hence, ischemic heart failure has still a great impact on both hospital admission and economic burden. Either transplantation or left ventricular assistance are considered the gold standard for the treatment of end-stage IHF, but both are limited by donor shortage and complication rates, respectively. ${ }^{3,4}$

For many years, heart tissue was considered not reparable, since after ischemic damage, cardiomyocytes were unable to regenerate cardiac tissue and therefore a fibrotic scar forms in place of it. ${ }^{5}$ However, in recent decades, stem cells started to be considered for the treatment of IHF, leading to their injection in different types of exogenous cells. In 2007, Smith and colleagues ${ }^{6}$ described the isolation procedure of cardiosphere-derived cells (CDCs) by means of a percutaneous endomyocardial biopsy. Since then, different attempts have been made to improve the potentiality of CDCs to differentiate, replacing scar with new myocardium. ${ }^{7-9}$ Hosoyama and colleagues ${ }^{7}$ demonstrated the role of hypoxia to prime CDCs implanted into the ischemic heart. In that condition, vascular endothelial

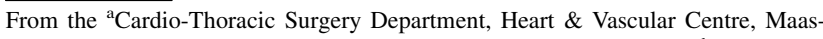
tricht University Medical Centre, Maastricht, The Netherlands; and ${ }^{\mathrm{b}}$ Department of Medicine and Aging Sciences, University "G. D'Annunzio," Chieti, Pescara, Italy.

Disclosures: The authors reported no conflicts of interest.

The Journal policy requires editors and reviewers to disclose conflicts of interest and to decline handling or reviewing manuscripts for which they may have a conflict of interest. The editors and reviewers of this article have no conflicts of interest.

Received for publication May 29, 2020; revisions received May 29, 2020; accepted for publication May 29, 2020; available ahead of print June 26, 2020.

Address for reprints: Michele Di Mauro, MD, PhD, MSc Biostat, Cardio-Thoracic Surgery Unit, Heart and Vascular Centre, Maastricht University Medical Centre (MUMC), Cardiovascular Research Institute Maastricht (CARIM), P. Debyelaan 25, 6202 AZ Maastricht, The Netherlands (E-mail: mdimauro1973@gmail.com). J Thorac Cardiovasc Surg 2022;163:1494-6

$0022-5223 / \$ 36.00$

Copyright (c) 2020 by The American Association for Thoracic Surgery

https://doi.org/10.1016/j.jtcvs.2020.05.116

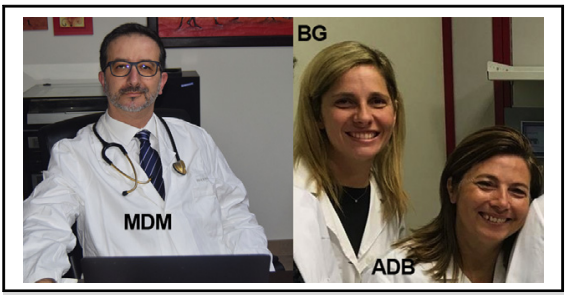

Michele Di Mauro, MD, PhD, MSc (MDM), Barbara Ghinassi, MD, PhD (BG), and Angela Di Baldassarre, MD, PhD (ADB)

\section{CENTRAL MESSAGE}

The power of myocardial repair

by cardiosphere-derived cells can

be enhanced using transcrip-

tional activators, acting on

selected cardio-specific genes.

growth factor production increased, and fibrosis was reduced. Takehara and collaegues ${ }^{8}$ investigated the priming role of pretreatment of CDCs with basic fibroblast growth factor. The isolation of CDCs from patients taking betablockers was shown to provide greater extraction of CDCs. Moreover, these CDCs showed a reduced expression of fibrosis-associated micro-RNAs, whereas there was a greater expression of cardiac regeneration-associated micro-RNAs. ${ }^{9}$

While we await phase 2 trial (ALLSTAR [ALLogeneic Heart Stem Cells to Achieve Myocardial Regeneration], DYNAMIC [Dilated cardiomYopathy iNtervention With Allogeneic MyocardIallyregenerative Cells]) results, ${ }^{10,11}$ the paper from Sano and collegues ${ }^{12}$ strengthens interest in CDCs, showing how to handle synthetic transcriptional activators derived from the clustered regularly interspaced short palindromic repeat (CRISPR)-Cas9 system to prime endogenous expression of genes. The authors selected some cardio-specific target genes (Gata4, Mef2c, Nkx2-5, Hand2, and Tnnt2) to verify whether dCas9-based transcriptional activators could regulate endogenous gene expression in CDCs using single and multiple sgRNAs, demonstrating significantly greater expression of differentiation factors such as Gata4, Hand2, and Tnnt2. The clinical epiphenomenon was a significant increase of left ventricular systolic function with respect to either CDCs without transcriptional activation or control group. Finally, CDCs with transcriptional activation showed a significant reduction of scar area. ${ }^{12}$

In 1966, Bernard Malamud, the Pulitzer Prize winner, wrote The Fixer, ${ }^{13}$ where he stated "I fix what's 
broken-except in the heart." Nowadays, we are closer and closer to saying "I fix what's broken-including the heart."

\section{References}

1. Benjamin EJ, Blaha MJ, Chiuve SC, Cushman M, Das SR, Deo R, et al. Heart disease and stroke statistics_-2017 update: a report from the American Heart Association. Circulation. 2017; 135:e146-603.

2. Moscucci M, Eagle KA. Door-to-balloon time in primary percutaneous coronary intervention: is the 90-minute gold standard an unreachable chimera? Circulation. 2006;113:1048-50.

3. Birati EY, Rame JE. Post-heart transplant complications. Crit Care Clin. 2014; 30:629-37.

4. Holley CT, Harvey L, John R. Left ventricular assist devices as a bridge to cardiac transplantation. J Thorac Dis. 2014;6:1110-9.

5. Murry CE, Pu WT. Reprogramming fibroblasts into cardiomyocytes. $N$ Engl J Med. 2011:364:177-8.

6. Smith RR, Barile L, Cho HC, Leppo MK, Hare JM, Messina E, et al. Regenerative potential of cardiosphere-derived cells expanded from percutaneous endomyocardial biopsy specimens. Circulation. 2007;115:896-908.
7. Hosoyama T, Samura M, Kudo T, Nishimoto A, Ueno K, Murata T, et al. Cardiosphere-derived cell sheet primed with hypoxia improves left ventricular function of chronically infarcted heart. Am J Transl Res. 2015;7:2738-51.

8. Takehara N, Tsutsumi Y, Tateishi K, Ogata T, Tanaka H, Ueyama T, et al Controlled delivery of basic fibroblast growth factor promotes human cardiosphere-derived cell engraftment to enhance cardiac repair for chronic myocardial infarction. J Am Coll Cardiol. 2008;52:1858-65.

9. Chimenti I, Pagano F, Cavarretta E, Angelini F, Peruzzi M, Barretta A, et al B-blockers treatment of cardiac surgery patients enhances isolation and improves phenotype of cardiosphere-derived cells. Sci Rep. 2016;6:36774.

10. Chakravarty T, Makkar RR, Ascheim DD, Traverse JH, Schatz R, DeMaria A et al. ALLogeneic Heart Stem Cells to Achieve Myocardial Regeneration (ALLSTAR) trial: rationale and design. Cell Transplant. 2017;26:205-14.

11. Dilated cardiomYopathy iNtervention With Allogeneic MyocardIallyregenerative Cells (DYNAMIC) - Full Text View - ClinicalTrials.gov; 2016. Available at: https://clinicaltrials.gov/ct2/show/NCT02293603?term=NCT02293603\&ran $\mathrm{k}=1$. Accessed May 25, 2017.

12. Sano T, Ito T, Ishigami S, Bandaru S, Sano S. Intrinsic activation of cardiospherederived cells enhances myocardial repair. J Thorac Cardiovasc Surg. 2022;163: 1479-90.e5.

13. Malamud B. The Fixer. New York: Farrar, Straus \& Giroux Ed; 1966. 